\title{
CONSTITUCIONALISMO ABUSIVO Y AMNISTÍA EN VENEZUELA
}

\section{ABUSIVE CONSTITUTIONALISM AND AMNESTY LAW IN VENEZUELA}

\author{
ANDRÉS CERVANTES VALAREZO*
}

Recibido: 06/04/2017

Aceptado: 12/06/2017

SUMARIO: I. INTRODUCCIÓN. II. CONSTITUCIONALISMO ABUSIVO: EL CASO VENEZOLANO. III. EL ABUSO DEL CONTROL DE CONVENCIONALIDAD COMO VIOLACIÓN A LOS DERECHOS HUMANOS. IV. ESTÁNDARES DE VALIDEZ DE LAS AMNISTÍAS. A) LA NATURALEZA DE LAS INFRACCIONES. B) LÍMITE A LAS DECISIONES DEMOCRÁTICAS Y AUTO AMNISTÍA. C) DERECHO A LA VERDAD, JUSTICIA Y REPARACIÓN. V. HACIA UN CONTROL DE CONVENCIONALIDAD CUASI-JURISDICCIONAL. VI. RESPONSABILIDAD INTERNACIONAL DEL ESTADO Y SANCIONES DE LA COMUNIDAD INTERNACIONAL. VII. CONCLUSIONES. VIII. BIBLIOGRAFÍA CITADA.

SUMARY: I. INTRODUCTION. II. ABUSIVE CONSTITUTIONALISM: VENEZUELA'S CASE. III. THE ABUSE OF JUDICIAL REVIEW AS A HUMAN RIGTHS VIOLATION. IV. STANDARDS FOR ASSESSING AMNESTY LAW VALIDITY. A) NATURE OF THE CRIMES. B) LIMITATIONS TO DEMOCRATIC RULING AND PROHIBITION OF SELF-AMNESTY LAWS. C) RIGHT TO TRUTH, JUSTICE AND COMPENSATION. V. A QUASI-JURISDICTIONAL CONVENTIONALITY CONTROL.VI. INTERNATIONAL STATE LIABILITY AND SANCTIONS OF THE INTERNATIONAL COMMUNITY. VII. CONCLUSIONS. VIII. BIBLIOGRAPHY.

Resumen: Este artículo constituye una crítica a la declaratoria de inconstitucionalidad total por parte de la Sala Constitucional del Tribunal Supremo de Justicia sobre la Ley de Amnistía y Reconciliación Nacional aprobada por la Asamblea Nacional de marzo del 2016. En primer lugar, se demostrará que la ley declarada inconstitucional cumplía con los estándares fijados por la jurisprudencia de la Corte Interamericana de Derechos Humanos relativos a los derechos a la verdad, justicia y reparación de las víctimas. Igualmente se demostrará que la ley no perdona graves violaciones de derechos humanos sino meros delitos políticos. Bajo estos presupuestos demostraremos que existe un constitucionalismo abusivo en Venezuela y las eventuales acciones y sanciones de la OEA y la comunidad internacional, pese a la denuncia de la Convención Interamericana de Derechos Humanos por parte de Venezuela en 2013.

Palabras clave: Control de convencionalidad -amnistías- impunidad-constitucionalismo abusivo.

\footnotetext{
* Abogado por la Universidad de Especialidades Espiritu Santo (Ecuador), LL.M y doctorando en Derecho por la Universitat Pompeu Fabra (España), Investigador Pre-doctoral (FI-AGAUR) del Grupo de Investigación de Derecho Constitucional de la misma Universidad. Agradezco especialmente al Profesor Alejandro Saiz Arnaiz por su guía y critica, siempre constructiva, indispensable para este trabajo. Número ORCID: 0000-0003-4644-3977.
} 


\begin{abstract}
This article constitutes a critic of the declaration of total unconstitutionality by the Constitutional Chamber of Venezuela's Supreme Court of Justice of the Law of Amnesty and National Reconciliation approved by the National Assembly of March 2016. First, it will be demonstrated that the amnesty law declared unconstitutional complies with the legal standards established by the jurisprudence of the Inter-American Court of Human Rights regarding the rights to truth, justice and reparation of victims. It will also be shown that the law does not forgive serious violations of human rights but rather political crimes. Finally, I will demonstrate that there is an abusive constitutionalism in Venezuela and analyze the possible actions and sanctions of the OAS and the international community, despite the denunciation of the InterAmerican Convention on Human Rights by Venezuela in 2013.
\end{abstract}

Keywords: Conventionality control -amnesty laws - impunity- abusive Constitutionalism.

\title{
I. INTRODUCCIÓN
}

Este trabajo analiza un caso de constitucionalismo abusivo o autoritario, expresiones que fueron utilizadas originariamente por Landau y Tushnet para explicar cómo varios regímenes autoritarios, entre los que incluyen a Venezuela, utilizaron mecanismos constitucionales, avalados por los más altos tribunales nacionales de sus respectivos países, para modificar la constitución de manera fraudulenta y mantenerse en el poder eliminando los límites a la reelección presidencial ${ }^{2}$. De otro lado, en este ensayo expandimos el uso del término "constitucionalismo abusivo" al referirnos al abuso del poder de control de constitucionalidad de las leyes, realizado en manifiesta contradicción a estándares internacionales de derechos humanos. Este fenómeno reúne la característica básica señalada inicialmente por Landau "el uso de mecanismos constitucionales para erosionar el orden democrático".

En la actualidad, Venezuela atraviesa una grave crisis económica, humanitaria y política, con ocasión de la permanencia en el poder de un mismo partido político durante más de 17 años, desde el 2 de febrero de 1999 con Hugo Chávez Frías, hasta el año 2016 con Nicolás Maduro Moros. Este mismo partido ha mantenido durante el mismo periodo una mayoría dominante en la Asamblea Nacional que es la titular del poder legislativo. De igual manera, el diseño institucional del poder público en Venezuela, además del poder político del gobierno, permitió que este asuma una toma de control de facto de la Sala Constitucional del Tribunal Supremo de Justicia (en adelante TSJ) que durante este periodo no ha dictado un solo fallo en contraposición a los intereses oficialistas. Sin embargo, desde el 6 de diciembre de 2015, los resultados

\footnotetext{
${ }^{2}$ LANDAU, D. “Abusive Constitutionalism”, University of California, Davis Law Review, Vol.47/2013, pp. 195 y ss. "The most prominent accounts of courts and constitutionalism in nations with authoritarian governments are strategic or instrumental. These accounts purport to show that, from their own point of view, authoritarian leaders can stabilize their regimes and thereby ensure that they remain in power by creating independent courts or, more generally, by tying their own hands through constitutional restraints”. TUSHNET, M. “Authoritarian Constitutionalism” Cornell Law Review, Vol.100/2015, pp. 391.
} 
de las elecciones parlamentarias dejaron saber que la nueva legislatura contaría con una mayoría calificada de dos tercios de las curules en manos de la oposición ${ }^{3}$.

En este contexto, la nueva Asamblea Nacional debatió y aprobó una ley de amnistía y reconciliación que tiene como objeto amnistiar delitos políticos cometidos durante el periodo comprendido entre los años 2007-2015, siempre que estos tengan relación con la libertad de expresión, protesta y orden institucional. La ley de amnistía prohíbe expresamente que la gracia aplique en casos de violación de derechos humanos, delitos de lesa humanidad y delitos de guerra. El presidente actual de Venezuela expresó de manera previa a la aprobación de la ley, que aquella no entraría en vigencia por considerarla una norma nula de auto amnistía. La constitución venezolana le permitía utilizar dos mecanismos: de un lado el veto presidencial; y, de otro, una consulta de constitucionalidad ante el Tribunal Supremo de Justicia.

Esta última fue la opción adoptada por el presidente de gobierno quien prescindió de su poder de veto y se sometió, teóricamente, al criterio que emitiera el TSJ sobre la validez o inconstitucionalidad de la norma en cuestión. Esta es sin duda alguna la característica primigenia del constitucionalismo abusivo descrito por Landau, la utilización del poder constitucional con pretensiones legitimadoras, en este caso, el control constitucional de las leyes en manos de un tercero independiente como -debería serlo- la Función Judicial en lugar de la utilización de medidas unilaterales, propias de las atribuciones del ejecutivo, como el veto presidencial que resultan cuestionables desde el punto de vista democrático. De igual forma, la constitución venezolana establece que este tipo de control constitucional debe efectuarse en un máximo de diez días desde que el recurso ha sido propuesto por el ejecutivo ante la Sala Constitucional del TSJ.

En caso de silencio o de una sentencia fuera de plazo, se entenderá que la norma fue declarada constitucional debiendo ser publicada en el registro oficial. Más allá de que el plazo de diez días es en extremo escaso para que cualquier Corte analice un caso de tamaña importancia nacional habida cuenta de su incidencia en cuestiones de derechos humanos es necesario destacar que en menos de una semana, el TSJ declaró inconstitucional por el fondo la totalidad de los artículos de la ley de amnistía. Es preciso recordar que durante el siglo XX y el siglo XXI América Latina ha sido testigo de violaciones sistemáticas de derechos humanos y de terrorismo de Estado

\footnotetext{
${ }^{3}$ Actualmente Venezuela enfrenta una de las mayores crisis democráticas, políticas y económicas de su historia republicana. Así, el TSJ venezolano llegó inclusive a declarar en desacato a la Asamblea Nacional decidiendo asumir sus funciones como legislador ordinario. Ello ha sido catalogado por la comunidad internacional como un golpe de Estado, aunque aún no se suspende a Venezuela de la OEA. Véanse los Acuerdos legislativos "en apoyo de la aplicación del artículo 20 de la Carta Democrática Interamericana, como mecanismo para el restablecimiento en paz del orden constitucional en Venezuela” (21/07/2017); el Acuerdo "sobre la activación del procedimiento de remoción de los Magistrados de la Sala Constitucional del Tribunal Supremo de Justicia, por su responsabilidad en la ruptura del orden constitucional" (05/04/2017); el Acuerdo "en rechazo a la ruptura del orden constitucional y la permanencia de la situación de golpe de Estado en Venezuela” (05/04/2017); o el Acuerdo “en emplazamiento a los demás poderes públicos para que cese la persecución política, y se convoquen elecciones en forma inmediata y en rechazo de la sentencia número 155 de la Sala Constitucional del TSJ del 28 de marzo de 2017”, recuperados el 6 de abril de 2017, en http://www.asambleanacional.gob.ve/documento/show2/id/58
} 
perpetrados por distintos estados miembros de la Organización de Estados Americanos (en adelante OEA). En este contexto, la Corte Interamericana de Derechos Humanos (en adelante CorteIDH) ha conocido catorce casos sobre leyes de amnistía en ejercicio de su jurisdicción contenciosa. Por la expedición y aplicación de este tipo de leyes han sido condenados siete países: Perú (4), Guatemala (3), El Salvador (2), Chile (2), Brasil (1), Surinam (1), y Uruguay (1) ${ }^{4}$.

En general, estos casos tienen como objeto la denuncia de las leyes de amnistía (y en general de las medidas de gracia que incluyen normas de prescripción penal e indultos presidenciales) como contrarias a los derechos humanos reconocidos en la Convención Americana de Derechos Humanos (en adelante CADH); específicamente, atentatorias de los derechos a la verdad, a la justicia y a la reparación de las víctimas.

En el caso venezolano, la falta de jurisdicción de la Corte IDH provocada por la denuncia del Estado de la CADH implica que la CorteIDH se encuentre impedida de ejercer el control de convencionalidad y dirimir sobre si la ley de amnistía aprobada por el legislativo venezolano es conforme o no con los postulados de la CADH y la jurisprudencia de la CorteIDH ${ }^{5}$. Sin embargo, aunque Venezuela haya denunciado la CADH, sigue sujeta a la cuasi-jurisdicción de la Comisión Interamericana de Derechos Humanos (en adelante CIDH) y a las sanciones político-económicas de la OEA. El fin último de este trabajo es establecer si este órgano, con fundamento en el alto grado de integración jurisprudencial a nivel mundial y el carácter excepcional de la normativa en cuestión, podría legítimamente ejercer una especie de control de convencionalidad cuasi-jurisdiccional con el objeto de impulsar sanciones ejecutivas que obliguen al Estado venezolano a respetar los mecanismos democráticos y los estándares internacionales en la materia.

\section{CONSTITUCIONALISMO ABUSIVO: EL CASO VENEZOLANO}

La constitución venezolana vigente instruye un sistema de control constitucional concentrado, es decir, el control de conformidad con la constitución de todos los actos normativos del poder público se encuentran sujetos a la jurisdicción de

\footnotetext{
${ }^{4}$ FERRER M.G, E. “Las siete principales líneas jurisprudenciales de la Corte Interamericana de Derechos Humanos aplicable a la justicia penal” Revista IIDH, Vol.59/2014, pp. 30 y ss.

${ }^{5}$ El Alto Comisionado de las Naciones Unidas para los Derechos Humanos avaló la ley de amnistía a través de un análisis legal solicitado expresamente por el poder ejecutivo del gobierno venezolano, señalando que la Ley de amnistía era conforme al derecho internacional. www.efe.com. "La ONU "decepcionada" con la inconstitucionalidad de la ley de amnistía venezolana”, recuperado el 6 de abril de 2017, en: http://www.efe.com/efe/america/politica/la-onu-decepcionada-con-inconstitucionalidad-de-leyamnistia-venezolana/20000035-2893964
} 
un solo órgano judicial, en este caso, de la Sala Constitucional del TSJ Venezolano. Además de la facultad de derogar con efectos generales una norma del poder legislativo o del ejecutivo por inconstitucionales, el TSJ como institución judicial, tiene otras importantes potestades vitales en una democracia, entre estas, desempeñarse como tribunal de casación, interpretar las leyes y autorizar el enjuiciamiento y juzgar a altas autoridades como al Presidente de Gobierno, Vicepresidente, Ministros, al Fiscal General, al Contralor Público, al Defensor del Pueblo, a los Asambleístas del poder legislativo e inclusive autorizar el enjuiciamiento de los integrantes del propio TSJ.

El fundamento legitimador más básico de la justicia constitucional es que aquella constituye un límite infranqueable al poder irracional de las mayorías y que se instituye como un garante de la división de poderes ente el poder ejecutivo, el legislativo y el judicial, a través del control de constitucionalidad de los actos del poder público que le permite anular actos de los tres poderes; la potestad de dirimir conflictos de competencia entre instituciones estatales; $y$, autorizar el juzgamiento de altos funcionarios públicos. Los constituyentes, conscientes del inmensurable poder otorgado al TSJ configuraron un estatuto constitucional que permita que aquel goce de "autonomía funcional, financiera y administrativa”.

Entre las garantías para asegurar la imparcialidad e independencia del TSJ se estableció a nivel constitucional que sus miembros deben ser nombrados a través de un proceso reglado y sujeto a control democrático. En primer término, los candidatos son preseleccionados por un "Comité de Postulaciones Judiciales", posteriormente por "el Poder Ciudadano" y lo más importante, son confirmados definitivamente por el pleno de la Asamblea Nacional, cuerpo legislativo de la República. De igual manera, los miembros del TSJ "sólo podrán ser removidos o suspendidos de sus cargos mediante los procedimientos expresamente previstos en la ley".

El día 6 de diciembre de 2015, los resultados de las elecciones legislativas arrojaron un resultado favorable a la oposición venezolana concediéndole una mayoría calificada de 112 asambleístas a la Mesa de la Unidad Democrática (MUD) frente a los 55 del Partido Socialista Unido de Venezuela (PSUV) liderado por Nicolás Maduro Moros. Esta elección constituyó un cambio de paradigma en razón de que el legislativo y el ejecutivo venezolano habían sido dominados durante doce años ininterrumpidos por el mismo partido político. En el ínterin hasta la posesión de la nueva Asamblea Nacional, los integrantes del legislativo saliente procedieron a nombrar en una sesión de emergencia el 22 y 23 de diciembre de 2015, fuera del periodo legislativo ordinario culminado el 15 de diciembre de 2015, a 12 jueces que integrarían el TSJ, compuesto por 6 salas especializadas y 32 jueces en total.

El procedimiento fue entendido como un fraude constitucional y una maniobra política para mantener el control del legislativo de manera indirecta a través de la Sala Constitucional del TSJ. Se estableció un modus operandi consistente en la renuncia y jubilación anticipada y masiva de magistrados del TSJ con el objeto de que la Asamblea Saliente, dominada por el PSUV, confirme el nombramiento de los nuevos

\footnotetext{
${ }^{6}$ Artículos 264, 265 y 266 de la Constitución de Venezuela, Gaceta Oficial de diciembre de 1999.
} 
jueces por un periodo de doce (12) años para ejercer un control político de los actos legislativos a través de la jurisdicción constitucional ${ }^{7}$.

Entre las graves intervenciones en la justicia destacan el aumento injustificado del número de integrantes del TSJ, la modificación de los requisitos de nombramiento de jueces, las denuncias formales ante la Asamblea Nacional sobre extorsión para la renuncia forzada de los ex magistrados del TSJ Porras y Ortiz Hernández; o el hecho de que uno de los candidatos a la Asamblea en 2015 por el PSUV, Calixto Ortega, fue designado -por la Asamblea Nacional saliente dominada por el PSUV-integrante de la Sala Constitucional del TSJ tras perder las elecciones parlamentarias representando al PSUV en el mismo año ${ }^{8}$. Human Rigths Watch (2004) ha señalado que "la amenaza más grave para los derechos humanos en Venezuela es la posibilidad de control político sobre el Tribunal Supremo facilitada por la nueva ley que pretende llenar de aliados al Tribunal" 9 .

La constante denuncia contra la falta de independencia e imparcialidad del sistema judicial venezolano se remonta como mínimo al año 2002, tras el fallido golpe de estado contra Hugo Chávez Frías, momento tras el cual el gobierno inició una toma de control anti-democrática a través de medios institucionales ${ }^{10}$. En este contexto, se produjeron sendas denuncias relacionadas a la represión de protesta social legítima, persecuciones políticas y la libertad de expresión ante la CIDH que posteriormente devinieron en medidas cautelares y sentencias de la Corte IDH que el TSJ venezolano declaró inejecutables por considerar que el SIDH se había extralimitado de sus funciones ${ }^{11}$. En este sentido, el Ministerio del Poder Popular para las Relaciones

\footnotetext{
${ }^{7}$ Artículo 264: "los magistrados o magistradas del Tribunal Supremo de Justicia serán elegidos o elegidas por un único período de doce años...”. Constitución de Venezuela, Gaceta Oficial de diciembre de 1999. ${ }^{8}$ www.versionfinal.com.ve. "Calixto Ortega y Christian Zerpa, entre magistrados principales del TSJ". Recuperado el 6 de abril de 2017, en http://versionfinal.com.ve/politica-dinero/calixto-ortega-y-christianzerpa-entre-magistrados-principales-del-tsj/

${ }^{9}$ HUMAN RIGTHS WATCH. "Manipulando el Estado de Derecho: Independencia del Poder Judicial amenazada en Venezuela”, Vol. 16, No. 3 (B)/2004.

10 “Mediante la Ley Orgánica del Tribunal Supremo de Justicia, en evidente fraude a la Constitución, se estableció que los magistrados del Tribunal Supremo podían ser removidos con el voto de la mayoría absoluta de los diputados, al crearse una causal de remoción que se denominó "revocación del acto administrativo renombramiento. Ello provocó la destitución o “jubilación” de los Magistrados que osaron no seguir la línea gubernamental, con lo cual el gobierno asumió un control absoluto del Tribunal Supremo de Justicia en general, y de cada una de sus Salas en particular, especialmente de la Sala Constitucional". BREWER-CARÍAS. "Los problemas del control del poder y el autoritarismo en Venezuela”, recuperada el día 6 de abril de 2017, en: http://www.brewercarias.com/Content/449725d9f1cb-474b-8ab241efb849fea8/Content/II,\%204,\%20671.\%20Brewer.\%20Sobre\%20el\%20control\%20del\%20poder.\%20 Libro\%20Homenaje\%20a\%20D.\%20Valad\%C3\%A9s,\%203-08.doc).pdf

${ }^{11}$ Si bien la postura del TSJ de no ejecutar fallos de la Corte IDH y recomendar la denuncia de la CADH encuentran su origen en fallos del año 2003, consideramos que los fallos más relevantes por su contenido son: sentencia n. ${ }^{\circ} 1.939$ de la Sala Constitucional del Tribunal Supremo de Venezuela de 18 de Diciembre de 2008 (Caso Abogados Gustavo Álvarez Arias y otros) y también la negativa de ejecución originada del caso Granier y otros (Radio Caracas Televisión) c. Venezuela. Por todos, AYALA CORAO, C. "Comentarios sobre la sentencia de la Sala Constitucional del Tribunal Supremo de Justicia de Venezuela (No. 1939) de fecha 18-12-08”, Revista de Estudios Constitucionales, Vol.7 (1)/2009, pp. 391395.
} 
Exteriores, en representación del Gobierno de Venezuela presentó la denuncia formal de la CADH el 6 de septiembre de 2012 - denuncia firmada por el entonces Canciller Nicolás Maduro Moros- y fue recibida el día 10 del mismo mes y año ${ }^{12}$.

De conformidad con lo establecido en el artículo 78.1 de la CADH, la mencionada denuncia surtió efecto a partir del 10 de septiembre de 2013 una vez cumplido el preaviso de un año previsto en dicho artículo. La CIDH expresó su preocupación sobre esta cuestión señalando que:

Las violaciones a derechos humanos que pudieran ocurrir en Venezuela después del 10 de septiembre de 2013, no podrán ser conocidas por la Corte Interamericana de Derechos Humanos. Ello va en detrimento de la protección de los derechos de los y las habitantes de Venezuela, quienes pierden una instancia de protección de sus derechos humanos... ${ }^{13}$

Sin embargo, la CIDH recalcó también que Venezuela, a pesar de haber denunciado la CADH, sigue sujeta a la “jurisdicción” de la Comisión IDH en materia de promoción y supervisión de derechos humanos en mérito de las obligaciones que emanan de la Carta de la OEA ${ }^{14}$. En este sentido, procederemos a analizar críticamente la sentencia dictada por la Sala Constitucional del TSJ por la cual se declara inconstitucional la ley de amnistía (2016) expedida por la Asamblea Nacional con el objeto de determinar su validez ante el derecho internacional $y$ al sistema interamericano de derechos humanos.

\section{EL ABUSO DEL CONTROL DE CONSTITUCIONALIDAD COMO VIOLACIÓN A LOS DERECHOS HUMANOS.}

Un Estado sometido a la jurisdicción de la Corte IDH se encuentra obligado a cumplir con la ratio decidendi de las sentencias expedidas por el tribunal interamericano puesto que aquellas surten un efecto general al establecer criterios objetivos para casos análogos, en este caso, los criterios de validez o nulidad de una medida de gracia ${ }^{15}$. De

\footnotetext{
${ }^{12}$ La posición de Venezuela de denunciar la CADH se remonta al gobierno de Hugo Chávez (1999-2013) bajo el argumento de la soberanía estatal. No fue una decisión unilateral del poder ejecutivo, en sentido estricto puesto que la Sala Constitucional del TSJ venezolano exhortó al ejecutivo a denunciar la convención tras negarse a cumplir una de sus sentencias argumentando que la Corte IDH se había extralimitado en sus funciones. Al respecto véase, OCHOA, M. J. "La protección de los derechos humanos en Venezuela frente a la denuncia de la CADH”. Revista Latinoamericana de Derechos Humanos, Vol.25/2015, pp. 196 y ss.

13 “CIDH manifiesta su profunda preocupación por efecto de la denuncia de la Convención Americana por parte de Venezuela”, recuperado el 6 de abril de 2017, en: http://www.oas.org/es/cidh/prensa/comunicados/2013/064.asp

${ }^{14}$ Nótese que de los 34 Estados miembros de la OEA solo 24 han ratificado la CADH. Los Estados no están sujetos a la jurisdicción contenciosa de la Corte por el solo hecho de ratificar la CADH, sino únicamente en caso de un reconocimiento especial (Art. $62 \mathrm{CADH}$ ). Hasta la fecha lo han hecho así 21 Estados.

15 "No tendría sentido afirmar la "anti convencionalidad” de la norma en una hipótesis particular y dejar incólume la fuente de violación para los casos que se presenten en el futuro”... “lejos de establecer una garantía de no repetición [...], se estaría abriendo la puerta a la reiteración de la violación”. [S]ería impracticable -y frustrante- requerir nuevos pronunciamientos de la Corte Interamericana que abarquen y resuelvan una serie indefinida de casos de la misma naturaleza, llevados a la consideración de aquélla, uno a uno, con el propósito de obtener la respectiva declaratoria de anti convencionalidad”. Corte IDH.
} 
otro lado, bajo el principio de unidad en la responsabilidad internacional del Estado "es imputable al Estado toda violación a los derechos reconocidos por la Convención por un acto del poder público o de personas que actúan prevalidas de los poderes que ostentan por su carácter oficial” ${ }^{16}$. Bajo esta primera aproximación es plausible considerar que una autoridad judicial estatal, como un Tribunal Constitucional, pueda violar el derecho internacional de los derechos humanos a través de un ejercicio abusivo de sus facultades, un ejercicio manifiestamente contrario al orden jurídico global. Igualmente, los jueces nacionales tienen la obligación de aplicar de oficio las reglas jurisprudenciales derivadas del control de convencionalidad y por ende la infracción de este deber generaría responsabilidad estatal ${ }^{17}$.

El proyecto de ley de Amnistía y Reconciliación Nacional, sancionada por la Asamblea Nacional de Venezuela el 29 de marzo de 2016 se encuentra fuera del alcance de un control individual de convencionalidad por parte de la Corte IDH en razón de que la denuncia de Venezuela surtió efecto el 10 de septiembre de 2013. Ello impide sin duda que la Corte IDH dicte una sentencia que requiera al Estado venezolano dejar sin efectos la sentencia del TSJ que declaró inconstitucional el proyecto de ley ${ }^{18}$. Sin embargo, como se ha sostenido a lo largo de este trabajo, existe un orden jurídico internacional que regula la validez o nulidad de las medidas de gracia, que no puede ser ignorado por un miembro de la Comunidad Internacional.

Previo a analizar la ponencia conjunta de la Sala Constitucional del TSJ dentro del expediente $\mathrm{N}^{\mathrm{0}} 16-0343$, del 11 de abril de 2016, que declara por unanimidad la inconstitucionalidad del proyecto de ley de amnistía hemos de advertir que aquella sentencia toma en cuenta criterios de derecho internacional, al punto de citar textualmente sentencias de la CorteIDH, pero arriba a conclusiones diametralmente opuestas a las arribadas por el Alto Comisionado de las Naciones Unidas para los Derechos Humanos.

De un lado, el TSJ declara la inconstitucionalidad por el fondo y en su totalidad de la ley de amnistía mientras que el órgano internacional ACNUDH, que envío al Estado un informe jurídico por petición expresa del gobierno venezolano y con

Caso La Cantuta Vs. Perú. Fondo, Reparaciones y Costas. Sentencia de 29 de noviembre de 2006. Serie C No. 162. Ver el voto particular del Juez García Ramírez, pp.2 y ss.

${ }^{16}$ CorteIDH, caso Velásquez Rodríguez c. Honduras, Sentencia de 29 de julio de 1988 (Fondo), pág. 36. Sobre el principio de unidad de la responsabilidad internacional del Estado véase, DEL TORO HUERTA. M. I. "La responsabilidad del Estado en el marco del derecho internacional de los derechos humanos". In Memoria del VII Congreso Iberoamericano de Derecho Constitucional, 2002, pp. 663-688.

17 “Los órganos del Poder Judicial deben ejercer no sólo un control de constitucionalidad, sino también de convencionalidad ex officio entre las normas internas y la Convención Americana...”. CorteIDH. Caso Trabajadores Cesados del Congreso (Aguado Alfaro y otros) Vs. Perú. Excepciones Preliminares, Fondo, Reparaciones y Costas. Sentencia de 24 de noviembre de 2006. Serie C No. 158, párr. 128.

${ }^{18}$ No es inviable ejercer control de convencionalidad sobre una decisión judicial nacional aunque esta haya sido expedida por la máxima autoridad judicial o constitucional-jurisdiccional. Por ejemplo, pese a que la Corte Suprema de Justicia haya avalado la prohibición de la reproducción pública de la película "la última tentación de Cristo” la Corte IDH declaró que el Estado violó el derecho a la libertad de expresión e inclusive requirió al Estado reformar su constitución. CorteIDH. Caso "La Última Tentación de Cristo" (Olmedo Bustos y otros) Vs. Chile. Fondo, Reparaciones y Costas. Sentencia de 5 de febrero de 2001. Serie C No. 73. 
anterioridad a la expedición de la sentencia ${ }^{19}$, concluyó que el proyecto se encontraba conforme al derecho internacional. Venezuela no cuenta con una ley que regule expresamente las instituciones de gracia, como la amnistía y el indulto, ello provocó que el TSJ al resolver la acción de inconstitucionalidad, propuesta por Nicolás Maduro Moros en contra de la ley de amnistía y reconciliación nacional, desarrollare una serie de criterios para determinar si ley era válida o no a través una especie de regulación judicial fundamentada en principios constitucionales.

En este sentido, la primera conclusión a la que arriba el TSJ es que las amnistías se adoptan en procesos de justicia transicional y que al ser una medida excepcional que permite la impunidad ${ }^{20}$ debe ser así mismo excepcional en su concesión. Posteriormente, el TSJ narra una breve historia sobre las amnistías en Venezuela y concluye:

...como se ha expuesto supra, las amnistías son manifestaciones de justicia transicional (I, 2), que refieren a verdaderos momentos de ruptura y la necesidad de instaurar una comunidad política, que no se aprecian como presupuesto y contexto de la situación de autos, lo que invalida de conformidad con la Constitución la ley bajo examen, tal como se evidencia del objeto de la misma (artículo 1) y el resto de sus normas. Así se decide. $^{21}$

Sobre este primer aspecto, es como mínimo cuestionable el rol que adopta el TSJ en una cuestión que escapa por mucho de la función judicial -la de determinar si existe "un momento de ruptura y necesidad de instaurar una comunidad política"- que le corresponde como mínimo a la sociedad civil y a instituciones políticas dentro de una democracia deliberativa. Este criterio es especialmente grave puesto que la justicia constitucional se ve enajenada de la realidad, al punto de poder adoptar una decisión sobre si existe o no un conflicto político en las siguientes circunstancias:

En la sentencia no se alude, analiza ni se contrasta el pronunciamiento en favor de la validez de la norma efectuado por la ACNUDH. De igual forma, El TSJ incumplió la máxima judicial de que no se puede sentenciar sin previamente haber escuchado en igualdad de condiciones a la otra parte (principio de contradicción) puesto que no

\footnotetext{
${ }^{19}$ Con evidentes efectos contraproducentes a los perseguidos por el gobierno venezolano. Según la canciller de la República venezolana, Delcy Rodríguez, la ley" violenta absolutamente toda la doctrina internacional en materia de Amnistía" motivo por el cual solicitó, en marzo de 2016, al Alto Comisionado de las Naciones Unidas para los Derechos Humanos, realizar un estudio "para que se evidencie el carácter anticonstitucional y violatorio de los Derechos Humanos que pretende la impunidad en un aspecto donde no corresponde". www.efe.com. "Venezuela pide a la ONU que investigue la constitucionalidad de la ley de amnistía”, recuperado el 6 de abril de 2017, en: http://www.efe.com/efe/america/politica/venezuelapide-a-la-onu-que-investigue-constitucionalidad-de-ley-amnistia/20000035-2855805

${ }^{20}$ Entendida como "la falta en su conjunto de investigación, persecución, captura, enjuiciamiento y condena de los responsables de las violaciones de los derechos protegidos por la Convención Americana, [bajo la obligación general del] Estado [de] combatir tal situación por todos los medios legales disponibles ya que la impunidad propicia la repetición crónica de las violaciones de derechos humanos y la total indefensión de las víctimas y de sus familiares". Corte IDH. Caso de los "Niños de la Calle" (Villagrán Morales y otros) Vs. Guatemala. Reparaciones y Costas. Sentencia de 26 de mayo de 2001. Serie C No. 77, párr. 100.

${ }^{21}$ TSJ Venezuela, (2016). SALA CONSTITUCIONAL, Ponencia Conjunta. Expediente No $16-0343$ del 11 de abril de 2016. Disponible en http://www.tsj.gob.ve/-/tsj-declara-inconstitucional-la-ley-de-amnistiay-reconciliacion-nacional
}

Revista de Estudios Jurídicos n 17/2017 (Segunda Época)

ISSN-e 2340-5066. Universidad de Jaén (España)

Versión electrónica: rej.ujaen.es 
existió oportunidad procesal para que ONG'S, la sociedad civil o el Representante Legal de la Asamblea Nacional ${ }^{22}$ presentaren su posición sobre el tema.

Además, la solicitud de consulta fue presentada al TSJ el día 7 de abril de 2016 y la sentencia fue expedida el día 11 del mismo mes y año, esto es un periodo de cuatro días, lo que difícilmente permitiría a un cuerpo judicial analizar la realidad económica, social y política de Venezuela, como de hecho sucedió puesto que en la sentencia no se realiza alusión alguna a los motivos que impulsan la expedición de la ley. Aún si admitiéramos que la decisión sobre la existencia misma de un conflicto sociopolítico en una sociedad debe corresponderle a un juez, el procedimiento adoptado en el caso de especie no brinda garantías suficientes de que el juzgador podrá razonablemente analizar todos los hechos necesarios para esta tarea, por ejemplo, el TSJ no analiza si el hecho de que Venezuela es en la actualidad el país con la mayor inflación a nivel mundial (180\%), o la grave crisis energética, alimenticia y las concurrentes violaciones de derechos humanos recogidas por la CIDH podrían llegar a constituir un conflicto dentro de la sociedad venezolana.

En fin, lo grave es que bajo este argumento, que como se explicó, no fue fruto de un procedimiento contradictorio ni ampliamente razonado por la sociedad toda, se declara la inconstitucionalidad total del proyecto de ley antes mencionado. Hemos de destacar que la ley de amnistía y reconciliación venezolana no es un "perdón en blanco" o incondicional de aquellos prohibidos expresamente por el derecho internacional. La norma dispone la creación de una Comisión Especial políticamente plural que redactará un informe final para decidir la creación de una Comisión de la Verdad y medidas de reivindicación moral o dignificación, de rescate de la memoria histórica y otras garantías de no repetición. Se evaluará igualmente la "creación de un fondo especial de reparaciones (Art.28).

No analizaremos el hecho de que el TSJ haya declarado la inconstitucionalidad de la amnistía de delitos comunes, que no son políticos en sentido estricto, pero que tienen indudable conexidad en casos de persecución institucionalizada, como por ejemplo, "el desacato de mandamiento de amparo constitucional" (Art.11), la difamación y la injuria (Art.9), "resistencia a la autoridad", "obstrucción de vía pública” o "daños a la propiedad” (Art.6). Sin duda alguna, el derecho a la resistencia y a la libertad de expresión tienen límites, sin embargo, exigir que toda protesta sea absolutamente pacifica además de materialmente imposible vaciaría a la amnistía de valor práctico. Ello cobra sentido cuando admitimos que el Estado, dentro de ciertos

\footnotetext{
${ }^{22}$ El criterio de la Asamblea Nacional de Venezuela fue claramente expuesto a través del “Acuerdo exhortando al cumplimiento de la Constitución y sobre la responsabilidad del poder Ejecutivo nacional, del Tribunal Supremo de Justicia y del Consejo Nacional Electoral para la preservación de la paz y ante el cambio democrático en Venezuela”, del 10 de mayo de 2016, en el que se señala “que actualmente Venezuela atraviesa la peor crisis de su historia republicana, debido a la grave situación de carencia de alimentos y medicamentos, los altos índices de violencia e inseguridad...", "Que el Tribunal Supremo de Justicia ha abandonado la función primordial que le asigna la Constitución de ser el último garante de la supremacía y efectividad de las normas y principios constitucionales, y actúa sistemáticamente como una instancia partidista e ideologizada, lo cual representa un grave riesgo para la estabilidad institucional”.
} 
límites es soberano, y que por tanto podría amnistiar infracciones conexas a un delito político siempre que estas no violen derechos humanos inderogables ${ }^{23}$.

En principio, el mismo argumento es oponible al TSJ cuando declara inconstitucional la amnistía de delitos políticos por antonomasia como "la organización, convocatoria o apoyo a la realización de manifestaciones o protestas que respondieran a una finalidad política" o "la expresión de ideas u opiniones o la difusión de informaciones de carácter político, de críticas al gobierno nacional u otras autoridades públicas..." (Art.5) por el hecho de que la ley "supone una generalización (que no excluye la violencia y el uso de las armas) en cuanto a las manifestaciones de protestas que no es admisible bajo el prisma constitucional...”. En el peor de los casos, bajo el principio pro legislatore o el de interpretación conforme, debió declararse que la ley era constitucional siempre que no se aplicare para amnistiar protestas que incluyan "violencia y el uso de armas"24.

Posteriormente, el TSJ sostiene que se trata de una ley de auto-amnistía, es decir, que quienes la expidieron serían sus beneficiarios directos con el fin último de garantizarse impunidad. Señala el TSJ que la "no exclusión de los miembros del órgano otorgante, del prófugo, evadido o no a disposición del sistema de justicia y del reincidente como posibles beneficiarios de la ley" les impide decretar la constitucionalidad de la norma. De nuevo podríamos invocar la presunción de la constitucionalidad de las actuaciones del legislador defendida por Thayer, o la interpretación conforme, que en el peor de los casos obligaría al TSJ a declarar la constitucionalidad condicionada de la norma. Sin embargo, debemos hacer las siguientes precisiones:

El TSJ declara inconstitucional la ley por considerarla de auto amnistía puesto que aquella tiene una "tipificación tan amplia que pudiera abarcar a Diputados o Diputadas reelectos o reelectas en las elecciones del 6 de diciembre de 2015, y que actualmente se encuentren en funciones". Sin embargo, hubiera bastado una interpretación que excluya de su ámbito de aplicación, como máxima garantía de que no

\footnotetext{
${ }^{23}$ La VI Conferencia Internacional para la Unificación del derecho penal, reunida en Copenhague en 1935, concluyó que: "...son delitos políticos: las infracciones dirigidas contra la organización o el funcionamiento del Estado, así como aquellos dirigidos contra los derechos que derivan para el ciudadano. Son reputados delitos políticos los delitos de derecho común que constituyen los medios que ponen en obra los atentados previstos en el 1párrafo primero, así como los actos cometidos para favorecer la ejecución de un pleito político o para permitir al autor de estos delitos escapar a la sanción de la ley penal. No obstante, no serán considerados como delitos políticos aquellos en, que el autor está determinado por un motivo egoísta o vil". MEDELLÍN, C. "Amnistía, Institución Iuspolítica”, Derecho Penal y Criminología, 11, Vol.259/1989.

${ }^{24}$ Citado por De Lora, Thayer señalaba que: “esta regla reconoce que, tomando en consideración las grandes, complejas y nunca del todo claras exigencias del gobierno, mucho de lo que sería inconstitucional para un hombre, o colectivo, puede razonablemente no serlo para otros; que la Constitución frecuentemente admite distintas interpretaciones; que hay frecuentemente un margen de elección y juicio; que en tales casos la Constitución no impone sobre el legislador una opinión específica, pero deja abierto ese margen de opción; que cualquier alternativa racional es por tanto constitucional”. DE LORA, P. "La Presunción de Constitucionalidad de las Leyes: Una Visita a la Regla Thayer". Teoría Constitucional y Derechos Fundamentales. Comisión Nacional de Derechos Humanos, México, 2002, pp. 409 y ss.
} 
se trata de una auto-amnistía, a todos los miembros de la Asamblea Nacional que sancionó la ley; y, el TSJ yerra al referirse a que un prófugo no puede acogerse a la amnistía. En primer lugar, porque sería ilógico que un perseguido político se someta voluntariamente, sin garantía alguna y de manera previa a la adopción de la amnistía, a la justicia de su perseguidor con los riesgos que ello acarrea.

Este mismo argumento cobija igualmente al “evadido” y al que no está “ $a$ disposición del sistema de justicia” puesto que el delincuente común y el político conservan derechos pese a no apersonarse en el proceso -contrario a la opinión del TSJsiendo prueba de ello la institución de la prescripción extintiva de la acción penal que opera precisamente en base a la falta de juzgamiento del reo.

En cuanto al "reincidente" resulta ilógico privarle de la posibilidad de sujetarse a una medida de gracia por el cometimiento de delitos políticos relacionados al ejercicio de la libertad de expresión porque su sola punición es injusta ${ }^{25}$. En segundo lugar, la afirmación del TSJ contradice su propia sentencia y la historia constitucional venezolana. En acápites anteriores de la sentencia, el TSJ destaca los momentos históricos los que se adoptaron medidas de gracia, tanto de indulto como de amnistía, en favor de ciudadanos que por motivos políticos estuvieran fuera del país. Por los argumentos expuestos anteriormente, consideramos que existió una especie de constitucionalismo abusivo en el caso de análisis puesto que el TSJ venezolano no se encuentra dotado de garantías sustanciales de imparcialidad e independencia y finalmente porque la sentencia es manifiestamente incompatible con el orden jurídico global en esta materia.

\section{ESTÁNDARES DE VÁLIDEZ PARA AMNISTÍAS}

El origen etimológico de la amnistía proviene del griego "amnesia” u “olvido" y es una medida preminentemente política, basada en el poder soberano de un Estado, que tiene efectos generales, que se toma en consideración a la infracción (delitos políticos y conexos) y no al reo; y, que produce la extinción de la acción penal. La amnistía no extingue sin embargo la antijuridicidad de la conducta del autor, sino únicamente su culpabilidad, haciendo cesar la condena en caso de que el individuo beneficiado por la medida se encuentre cumpliendo la pena. El fin que persigue esta medida es establecer la paz y concordia social ${ }^{26}$.

\footnotetext{
25 "The UN expert JOINET criticizes the use of amnesties to remedy injustice: On strict grounds of principle, granting amnesty to a prisoner of opinion is tantamount to an implicit acknowledgment that his conduct was criminal, whereas it is really the authority responsible for the penalty, being guilty of unlawful detention [that] might be granted amnesty. The proper remedy for such an injustice is the reversing of a judgment or retroactively repealing an illegitimate law. Amnesties are poor substitutes; they fail to acknowledge that the law was either wrong or wrongly applied, and thus are less effective in erasing the stigma of wrongdoing that attaches to an individual accused of violation”. SLYE, R. "Legitimacy of Amnesties under International Law and General Principles of Anglo-American Law: Is a Legitimate Amnesty Possible", the Seattle University School of Law Digital Commons, Vol. 43, 173/2002, pp. 174-215.

${ }^{26}$ MEZA, M. A. "La contribución de la jurisprudencia de la corte interamericana de derechos humanos a la eliminación de las «leyes de amnistía» en América Latina: un paso decisivo en la lucha contra la impunidad”. Recuperado el 6 de abril de 2017, en:
} 
Hemos de expresar que la CADH no regula expresamente lo relativo a la validez o nulidad de las leyes de amnistía, sino que esta regulación se ha dado a través de la interpretación de la convención por parte de la CorteIDH, dictadas en ejercicio de su jurisdicción contenciosa y con relación al auge de peticiones individuales y de víctimas formuladas en las décadas de los años 70, 80 y 90, relacionadas a la expedición de las llamadas leyes “de auto amnistía”, que eliminaban la responsabilidad penal de personas -especialmente policías, militares y políticos- que habían cometido crímenes de terrorismo de estado en las dictaduras latinoamericanas de la época.

En el ámbito interamericano, la Corte IDH determina, a través del control de convencionalidad, la compatibilidad de actos normativos del derecho interno de un Estado con la CADH y el corpus iuris interamericano de derechos humanos ${ }^{27}$; tiene como fundamento axiológico la supremacía del derecho internacional reconocida en el artículo 27 de la Convención de Viena sobre el derecho de los Tratados de 1969, norma por la cual los Estados deben cumplir sus obligaciones de buena fe, siendo ilícito invocar su derecho interno para el incumplimiento de obligaciones que dimanan del derecho internacional; en este caso, del Pacto de San José de Costa Rica ${ }^{28}$.

Con independencia de la jerarquía normativa que reconozca el derecho interno de cada Estado a la $\mathrm{CADH}$, aquellos que han ratificado la convención lo han hecho basados en un ejercicio de soberanía externa que los obliga a "respetar los derechos y libertades reconocidos en la Convención y a garantizar su libre y pleno ejercicio a toda persona que esté sujeta a su jurisdicción"29. De tal suerte, si bien la CADH no contiene norma alguna que faculte expresamente a la Corte IDH a derogar ipso facto las normas o actos internos de los Estados que resulten contrarios a la convención, el artículo 2 de aquella dispone que: "los Estados Parte se comprometen a adoptar, con arreglo a sus procedimientos constitucionales y a las disposiciones de esta Convención, las medidas legislativas o de otro carácter que fueren necesarias para hacer efectivos tales derechos y libertades".

En este sentido, todos los Estados sometidos a la jurisdicción de la Corte IDH tienen dos obligaciones fundamentales: por un lado, suprimir normas y prácticas de cualquier naturaleza que entrañen violación a las garantías previstas en la convención o que desconozcan los derechos allí reconocidos u obstaculicen su ejercicio; y, por otro, la obligación de expedir normas y fomentar el desarrollo de prácticas conducentes a la efectiva observancia de dichas garantías.

https://hal.archives-ouvertes.fr/file/index/docid/531553/filename/AT16_Arenas.pdf

${ }^{27}$ El control de convencionalidad se extiende al Protocolo de San Salvador; el Protocolo Relativo a la Abolición de la Pena de Muerte; la Convención para Prevenir y Sancionar la Tortura; la Convención de Belém do Pará para la Erradicación de la Violencia contra la Mujer, la Convención sobre Desaparición Forzada, entre otros; que integran el corpus iuris convencional de los derechos humanos, como repetidamente lo ha venido sosteniendo la Corte IDH.

${ }^{28}$ Véase, CorteIDH. Caso La Cantuta Vs. Perú. Fondo, Reparaciones y Costas. Sentencia de 29 de noviembre de 2006. Serie C No. 162.; igualmente CorteIDH. Caso Boyce y otros Vs. Barbados. Supervisión Cumplimiento Sentencia. Resolución de la Corte Interamericana de Derechos Humanos de 21 de noviembre de 2011.

${ }^{29}$ OVALLE, J. “La influencia de la jurisprudencia de la Corte Interamericana de Derechos Humanos en el derecho interno de los Estados latinoamericanos”. Boletín mexicano de derecho comparado, 45(134)/2012, pp. 595-623. 
En consecuencia, todo el derecho interno de los estados parte se encuentra sujeto en su validez sustancial, interpretación y aplicación, al $\mathrm{SIDH}^{30}$. Este poder alcanzaría incluso a normas de carácter constitucional, y en consecuencia, a toda norma $\mathrm{u}$ acto derivado o ejercitado con fundamento en ella, lo que incluye a las medidas de gracia como indultos y amnistías, limitando de este modo la soberanía interna de los Estados e imponiendo restricciones aún a la voluntad de las mayorías populares ${ }^{31}$. La CorteIDH ha demostrado a través de su jurisprudencia una sólida postura generalmente contraría a la concesión de medidas de gracia puesto que a través de aquellas se estaría garantizando la impunidad y violando el derecho de las víctimas a conocer la verdad en relación a los hechos, el derecho a la reparación integral y el derecho a la tutela judicial efectiva puesto que las medidas de gracia impiden accionar el sistema judicial penal (más allá de las comisiones de la verdad y reparaciones civiles) que sería, en palabras de la CorteIDH, el medio idóneo para descubrir la verdad material y responsabilizar a los culpables $^{32}$.

Sin duda, las medidas de gracia son absolutamente necesarias en procesos de justicia transicional donde la violación sistemática de derechos humanos amenaza la existencia del Estado mismo. En este sentido, para que una ley de amnistía sea jurídicamente válida - al menos de acuerdo a la jurisprudencia de la CorteIDH- deben cumplirse tres requisitos escalonados relativos a la naturaleza de las infracciones perdonadas $^{33}$, la proporcionalidad de la medida de gracia en relación al derecho a la verdad, a la reparación y al acceso a la justicia de las víctimas; y, que la medida de gracia se haya adoptado en un régimen de democracia deliberativa, caracterizado por la independencia de los poderes internos de un Estado y la participación de la ciudadanía. en el debate y toma de decisiones, dado el carácter excepcional de las medidas de gracia.

\footnotetext{
${ }^{30}$ “Cuando dicho cuerpo jurisdiccional -luego de hacer el control de marras-, dispone que en el caso concreto se violó la convención, tal pronunciamiento es vinculante (arts. 62.3 y 68.1 del Pacto), y el Estado -tal cual vimos-, tiene la obligación de adaptar y en su caso modificar el derecho interno, incluyendo la propia Constitución como ocurrió en el caso de La Última Tentación de Cristo vs. Chile, bajo apercibimiento de incurrir en Responsabilidad Estatal...". Hitters, J. C. "Control de constitucionalidad y control de convencionalidad. Comparación (Criterios fijados por la Corte Interamericana de Derechos Humanos)”. Estudios constitucionales, 7(2)/2009, pp. 109-128.

31 “...la Corte es asimismo competente para decidir si cualquier norma del derecho interno o internacional aplicada por un Estado...es compatible o no con la Convención Americana. En esta actividad, la Corte no tiene ningún límite normativo: toda norma jurídica es susceptible de ser sometida a este examen de compatibilidad...”. CorteIDH. Caso Las Palmeras Vs. Colombia. Fondo. Sentencia de 6 de diciembre de 2001. Serie C No. 90.

32 “....ante la gravedad de determinados delitos, las normas de derecho internacional consuetudinario y convencional establecen el deber de juzgar a sus responsables...lo que genera para los Estados la obligación de asegurar que estas conductas sean perseguidas penalmente y sancionados sus autores”. Corte IDH. Caso Goiburú y otros Vs. Paraguay. Fondo, Reparaciones y Costas. Sentencia de 22 de septiembre de 2006. Serie C No. 153.

33 “...no desconozco la alta conveniencia de alentar la concordia civil a través de normas de amnistía que contribuyan al restablecimiento de la paz y a la apertura de nuevas etapas constructivas en la vida de una nación. Sin embargo...esas disposiciones de olvido y perdón no pueden poner a cubierto las más severas violaciones a los derechos y repugnan a la conciencia de la humanidad”. Voto concurrente del Juez Sergio García Ramírez, párr. 11 a 14 en Corte IDH, Caso Barrios Altos v. Perú, fondo, sentencia de 14 de marzo de 2001, Serie C No. 75.
} 


\section{A. LA NATURALEZA DE LAS INFRACCIONES:}

En nuestro criterio, el primer filtro que debe analizarse para juzgar la validez o nulidad de una ley de amnistía bajo la jurisprudencia interamericana es el tipo de infracciones que perdona, como ha sentenciado la Corte IDH, "se encuentran excluidos de la amnistía crímenes de lesa humanidad como la desaparición forzada, la tortura, el genocidio" entre otros ${ }^{34}$. Esta interpretación se deriva de una interpretación literal del Estatuto Penal de Roma que reconoce la existencia del "deber de todo Estado -deejercer su jurisdicción penal contra los responsables de crímenes internacionales" con el objeto de "poner fin a la impunidad de los autores de esos crímenes", lo que derivaría en la regla por deducción de que el derecho de gracia no sería aplicable bajo ningún concepto a crímenes internacionales de genocidio, crímenes contra la humanidad, crímenes de guerra y otras infracciones graves al derecho internacional humanitario ${ }^{35}$. Así, la Corte IDH ha señalado:

...son inadmisibles las disposiciones de amnistía, las disposiciones de prescripción y el establecimiento de excluyentes de responsabilidad que pretendan impedir la investigación y sanción de los responsables de las violaciones graves de los derechos humanos...prohibidas por contravenir derechos inderogables reconocidos por el Derecho Internacional de los Derechos Humanos (CORTE IDH, 2001) ${ }^{36}$.

De otro lado, existen comportamientos que por su naturaleza son lícitos, legítimos bona per se, el ejercicio de determinados derechos y libertad pero que el poder, por razones políticas, los tipifica como delictivos prohibiéndolos y castigándolos mala quia prohibita en estos casos estamos ante un verdadero delito político, susceptible de amnistía. Nos referimos al fenómeno de la criminalización de la protesta social, a través del abuso de tipos penales, donde se pondera de un lado el legítimo derecho ciudadano a la libertad de expresión y el derecho a resistir y de otro lado, el bien jurídico de la institucionalidad y orden estatal.

En este sentido:

\footnotetext{
${ }^{34}$ Son delitos no sujetos a amnistía el genocidio, la tortura, el exterminio, la esclavitud, el asesinato, la deportación o traslado forzoso de población, el encarcelamiento arbitrario, violación, esclavitud sexual, prostitución forzada, embarazo forzado, esterilización forzada, persecución racial o religiosa, apartheid. CorteIDH, caso Almonacid Arellano y otros vs. Chile. Excepciones Preliminares, Fondo, Reparaciones y Costas, 26 de septiembre de 2006, Serie C No 154, párr. 96-100.

${ }^{35}$ Las doctrinas de lucha contra la impunidad...Propugnan, pues, un recurso irrestricto al Derecho penal. En esta línea, no sólo rechazan los modelos de renuncia incondicionada al Derecho penal, sino también las propuestas en las que se admite una renuncia condicional a la atribución de responsabilidad penal (por ejemplo, si tiene lugar una confesión antes las comisiones de verdad) o en las que se acepta una significativa atenuación condicionada de dicha responsabilidad...”. Vease, SÁNCHEZ, J. M. S. "Nullum Crimen Sine Poena-Sobre las Doctrinas Penales de la Lucha Contra la Impunidad y del Derecho de la Victima al Castigo del Autor”. Revista de Estudios de la Justicia, Vol.11/2009, pp. 38.

${ }^{36}$ Corte IDH. Caso Trabajadores Cesados del Congreso (Aguado Alfaro y otros) Vs. Perú. Excepciones Preliminares, Fondo, Reparaciones y Costas. Sentencia de 24 de noviembre de 2006. Serie C No. 158.
} 
...la actuación dirigida contra el Estado ilegítimo o contra el ejercicio ilegítimo del poder público que viola el orden constitucional y los derechos humanos reconocidos y garantizados por el mismo... se trata en este caso de una acción legítima, bona per se, que encontraría su fundamentación ético-jurídica en el derecho de resistencia frente al poder injusto. Dicho derecho...constituye un "derecho humano universal ${ }^{37}$.

Sin duda alguna, este conflicto entre protesta social y derecho penal se ha evidenciado especialmente durante el siglo XX y lo que va del siglo XXI en varios países latinoamericanos, sin embargo, para los fines de este trabajo nos enfocaremos principalmente en Venezuela, país en el que en los últimos cinco años se registraron más de 2240 manifestantes sometidos a procesos penales y donde sólo en el año 2009, se contabilizaron 3297 manifestaciones públicas, de las cuales 194 fueron reprimidas por cuerpos de seguridad del Estado y en ellas se detuvieron a 754 manifestantes ${ }^{38}$. Al respecto, la CIDH (2010) señaló que:

En Venezuela la respuesta institucional a las manifestaciones pacíficas se ha caracterizado por la criminalización de la protesta social a través de la persecución penal a las personas involucradas, desvirtuando la aplicación de las leyes punitivas del Estado. Esta situación resulta de particular preocupación en tanto la represión y las penas privativas de la libertad para las personas que participan en acciones de protesta tienen por efecto inducir a los actores sociales a no participar en manifestaciones pacíficas.

Además, se han implementado tácticas como el agravamiento de las imputaciones vertidas contra los manifestantes que pudieren constituir, a lo mucho, una contravención como "resistencia a la autoridad" u "obstrucción del tráfico" por infracciones penales graves como los delitos de "tentativa de sedición" o “terrorismo"39. En este sentido, la CIDH (2015) ha señalado, en relación a Venezuela, que "el abuso de tipos penales vagos y ambiguos, que permiten la atribución de responsabilidades a quienes participan o convocan a una manifestación, genera un efecto amedrentador en el ejercicio del derecho a la protesta, que resulta incompatible con los principios democráticos $" 40$.

\footnotetext{
${ }^{37}$ Véase al respecto, SYAMPA, M., \& PANDOLFI, C. "Las vías de la criminalización de la protesta en Argentina”. Observatorio Social de América Latina, Vol. 5(14)/2004, pp.285-296.

38 AYALA CORAO, C. “La criminalización de la protesta en Venezuela”, ¿Es legítima la criminalización de la protesta social?, Centro de estudios en libertad de expresión y acceso a la información, Universidad de Palermo, Argentina, 2010, pp. 209-234.

40 Comunicado de prensa del 25 de septiembre de 2015 de la CIDH No. 107/15, titulado: “CIDH manifiesta su preocupación ante la sentencia contra Leopoldo López en Venezuela”, recuperado el 6 de abril de 2017, en: http://www.oas.org/es/cidh/prensa/comunicados/2015/107.asp
} 


\section{B. LÍMITE A LAS DECISIONES DEMOCRÁTICAS Y PROHIBICIÓN ABSOLUTA DE LA AUTOAMNISTÍA:}

Las leyes de auto-amnistía se encuentran per se prohibidas por el derecho internacional por ser, en palabras del ex juez interamericano García Ramírez, "una afrenta inadmisible a la conciencia jurídica de la humanidad" 41 . Hemos de distinguir entre las leyes de auto amnistía, aquellas que son adoptadas de forma generalmente previa a la transición por el régimen culpable de graves violaciones de derechos humanos para procurarse impunidad (sirva de ejemplo las leyes tituladas de "caducidad de pretensión punitiva del Estado", las amnistías absolutas o en blanco o las que declaran la prescripción de iure); y, las leyes de amnistía en que son adoptadas en un régimen de transición a la democracia como resultado de un debate político legítimo entre ciudadanos. En relación a las leyes de auto amnistía, es preciso citar el voto concurrente Cançado Trindade en el caso Barrios Altos c. Perú (2001) que señaló:

Las leyes de auto amnistía... no tienen validez jurídica alguna a la luz de la normativa del Derecho Internacional de los Derechos Humanos. Son más bien la fuente (fons et origo) de un acto ilícito internacional: a partir de su propia adopción (tempus commisi delicti), e independientemente de su aplicación posterior, comprometen la responsabilidad internacional del Estado. Su vigencia crea per sé una situación que afecta de forma continuada derechos inderogables, que pertenecen, como ya lo he señalado, al dominio del jus cogens ${ }^{42}$.

Así, las normas de auto amnistía serán siempre nulas ab initio por el principio de que quien cometió un crimen no puede decidir sobre su propia responsabilidad. De otro lado, las amnistías democráticas tendrán validez sustancial siempre que no violen normas inderogables por el derecho internacional, principalmente las relativas a la naturaleza de las infracciones amnistiadas. Al respecto, la Corte IDH señaló en el caso Gelman c. Uruguay (2011):

El hecho de que la Ley de Caducidad haya sido aprobada en un régimen democrático y aun ratificada o respaldada por la ciudadanía en dos ocasiones no le concede, automáticamente ni por sí sola, legitimidad ante el Derecho Internacional...la participación de la ciudadanía con respecto a dicha Ley, utilizando procedimientos [constitucionales] de ejercicio directo de la democracia...se debe considerar, entonces, como hecho atribuible al Estado y generador, por tanto, de la responsabilidad internacional de aquél...la sola existencia de un régimen democrático no garantiza, per se, el permanente respeto del Derecho Internacional, incluyendo al Derecho Internacional de los Derechos Humanos" ${ }^{43}$.

\footnotetext{
${ }^{41}$ Voto concurrente del Juez Sergio García Ramírez; CorteIDH, caso Almonacid Arellano y otros vs. Chile. Excepciones Preliminares, Fondo, Reparaciones y Costas, 26 de septiembre de 2006, Serie C N 154, párr. 105-129.

${ }^{42}$ Véase el respecto el voto concurrente del Juez Cançado Trindade en el caso Barrios Altos c. Perú, párrafo 11. Corte IDH, Caso Barrios Altos Vs. Perú. Fondo. Sentencia de, 14. (2001). 14, 41-44.

43 “La legitimación democrática de determinados hechos o actos en una sociedad está limitada por las normas y obligaciones internacionales de protección de los derechos humanos reconocidos en tratados como la Convención Americana”. Corte IDH. Caso Gelman vs. Uruguay. Fondo y Reparaciones. Sentencia de 24 de febrero de 2011. Serie C No. 221, párr. 193.
} 
En general, la Corte IDH (2011) ha señalado, en clara alusión a lo que Luigi Ferrajoli denomina "la esfera de lo indecidible", que la protección de los derechos humanos constituye un límite infranqueable a la regla de mayorías, es decir, la esfera de lo susceptible de ser decidido y que por tanto las prohibiciones sobre leyes de amnistía en caso de violación de derechos humanos se extienden no solo a las funciones estatales sino también a los ciudadanos cuando participan en actos de democracia directa, como plebiscitos o referéndums vinculantes ${ }^{44}$.

\section{DERECHO A LA VERDAD, JUSTICIA Y REPARACIÓN:}

La Corte IDH ha señalado que el derecho a la verdad no debe limitarse a que los hechos sean esclarecidos a través de una sentencia judicial en favor de los familiares de las víctimas sino que "la sociedad en su conjunto" tiene derecho a saber la verdad sobre los acontecimientos, por ello, ha condenado en sendas ocasiones a que los estados reconozcan públicamente por diferentes medios la violación de derechos humanos ${ }^{45}$. De otro lado, la CorteIDH ha señalado que un verdadero acceso a la justicia no debe limitarse únicamente a procedimientos civiles o administrativos sino que debe encausarse principalmente a través de un procedimiento penal:

...el Estado tiene la obligación de combatir tal situación por todos medios legales disponibles ya que la impunidad propicia la repetición crónica de las violaciones de derechos humanos y la total indefensión de las víctimas sus familiares ${ }^{46}$.

De igual manera, la jurisprudencia internacional aboga por la "reparación in integrum" de las víctimas por lo que la amnistía incondicional o en blanco es asimismo nula en la jurisprudencia de la CorteIDH. Roberto Gargarella critica la posición de la Corte IDH señalando que su interpretación -del procedimiento penal como remedio idóneo para la satisfacción del derecho a la verdad de la víctima- no deriva del texto expreso de la CADH y que constituye un grave impedimento a los procesos transicionales dado que se resta valor al hecho de que la decisión de renunciar al castigo penal haya sido adoptada democráticamente, caso en el cual los tribunales internacionales han de mostrar especial cautela y deferencia ante la jurisdicción interna

\footnotetext{
${ }^{44}$ Sobre esta cuestión debo hacer una reserva. Existen suficientes argumentos filosóficos y jurídicos para desafiar la posición de la CorteIDH sobre amnistías, puesto que, de acuerdo a los parámetros impuestos por su jurisprudencia cualquier amnistía se vuelve prácticamente inviable. De hecho, la historia ha demostrado que las víctimas pueden, en ejercicio de la regla de mayoría (democracia directa) prescindir del castigo penal e inclusive del derecho a la reparación pues consideran a la amnistía como una cláusula de supervivencia del Estado, véase como ejemplo el caso del apartheid sudafricano o el caso Gelman vs. Uruguay. Por todos, MALARINO, E. "Breves reflexiones sobre la justicia de transición a partir de las experiencias latinoamericanas”. Justicia de Transición: con informes de América Latina, Alemania, Italia y España. Montevideo: Fundación Konrad-Adenauer-Stiftung, Alemania, 2009, pp. 415-431.

${ }^{45}$ CorteIDH, caso de las Masacres de Ituango Vs. Colombia, excepción preliminar, fondo, reparaciones y costas, sentencia de 1 de julio de 2006, Serie C No. 148, párr. 299 y 402.

${ }^{46}$ CorteIDH, Caso "Panel Blanca” (Paniagua Morales y otros) Vs. Guatemala. Sentencia de 8 de marzo de 1998. Serie C No. 37, párr. 173.
} 
por un principio de legitimidad de ejercicio e inmediación en el conflicto. Gargarella critica también la idea de imponer un castigo penal, puesto que la pena es entendida como la imposición deliberada de dolor sobre un ser humano, dado que este requerimiento tampoco se desprende del texto expreso de la $\mathrm{CADH}$, que es el instrumento sobre el cual la CorteIDH ha sido autorizada para ejercer jurisdicción. Gargarella argumenta también que sería viable una renuncia a la justicia penal cuando los derechos de las víctimas a la verdad, justicia y reparación sean satisfechos por equivalencia, esto es, a través de comisiones cuasi-jurisdiccionales que establezcan la verdad y la memoria histórica, a través de indemnizaciones pecuniarias, medidas de reintegración social, entre otras ${ }^{47}$.

\section{HACIA UNA CONTROL DE CONVENCIONALIDAD CUASI- JURISDICCIONAL.}

Como se mencionó anteriormente, la CIDH liberó un comunicado de prensa el 10 de septiembre de 2013 en el que señalaba que pese a la denuncia de Venezuela a la CADH y la jurisdicción de la Corte IDH, este órgano cuasi-jurisdiccional de la OEA seguiría teniendo facultad o en los términos utilizados por sus representantes “jurisdicción” para conocer violaciones de derechos humanos posteriores a la denuncia del estado con fundamento en la Carta de la OEA, el reglamento de la CIDH y el corpus iuris interamericano, excluyendo por obvias razones al Pacto de San José. En este sentido, es necesario analizar bajo que procedimientos y que efectos tendrán las actuaciones de la CIDH en relación a Venezuela ${ }^{48}$.

En otro ámbito, la CIDH tiene competencia para conocer peticiones individuales, en razón de su competencia, fundada en el artículo 30 del reglamento, para conocer "presuntas violaciones de los derechos humanos consagrados en la Convención Americana sobre Derechos Humanos y otros instrumentos aplicables, con relación a los Estados miembros de la OEA”. Este procedimiento también se encuentra ceñido al debido proceso y al principio de contradicción procesal, de tal manera, el Estado tiene derecho a presentar su defensa y descargos en el plazo de 3 meses luego de que se ponga en su conocimiento la petición (Art.30.1 y 30.2).

Existe un procedimiento que regula la admisibilidad de la petición como el “agotamiento de recursos internos” (Art.31), que la petición no sea extemporánea (Art. 32), que no exista otro procedimiento con identidad objetiva y subjetiva tramitándose (Art.33) y otras causales de inadmisión como las peticiones que resulten

\footnotetext{
${ }^{47}$ GARGARELLA, R. "La democracia frente a los crímenes masivos: una reflexión a la luz del caso Gelman”, recuperado el 6 de abril de 2017, en: https://law.yale.edu/sites/default/files/documents/pdf/sela/SELA13_Gargarella_CV_Sp_20120924.pdf

48 En el caso de Venezuela es aplicable el artículo 51 del reglamento de la CIDH que dispone: "la Comisión recibirá y examinará la petición que contenga una denuncia sobre presuntas violaciones de los derechos humanos consagrados en la Declaración Americana de los Derechos y Deberes del Hombre con relación a los Estados miembros de la Organización que no sean partes en la Convención Americana sobre Derechos Humanos”.
} 
manifiestamente infundadas o improcedentes (Art.34). Así mismo, existe un procedimiento para decidir el fondo del asunto tras haber superado el filtro relativo a la admisibilidad de la petición. Este procedimiento respeta el derecho a la defensa e igualdad procesal de las partes puesto que tanto los peticionarios como los Estados tienen derecho a presentar "observaciones adicionales sobre el fondo".

El procedimiento de petición individual cumple con requisitos procesales relativos a la oralidad e inmediación puesto que la CIDH podrá convocar a las partes a una audiencia de forma previa a decidir sobre el fondo. Finalmente, el informe sobre el fondo del asunto cumple requisitos como motivación jurídica, fundados inclusive con jurisprudencia dictada por la Corte IDH en casos análogos, que consideran "los alegatos, las pruebas suministradas por las partes, y la información obtenida durante audiencias y observaciones in loco" (Art.43.1).

De igual manera, es lícito que las partes lleguen a un acuerdo amistoso que ponga fin a la controversia (Art.37.4 y 40) sin necesidad de que la Corte IDH se pronuncie sobre su procedencia. Finalmente, en caso de que no exista acuerdo entre las partes, es potestad exclusiva de la CIDH “establecer una o más violaciones” por parte del Estado y dictar las "recomendaciones que juzgue pertinentes" obligando al Estado a "informar sobre las medidas adoptadas para cumplir las recomendaciones".

El motivo de haber descrito un procedimiento complejo es demostrar que las decisiones de la CIDH son vinculantes porque derivan de un procedimiento cuasijurisdiccional respetuoso del debido proceso. Solo en caso de incumplimiento de las recomendaciones por el Estado, considerado de motu propio por la CIDH, el caso será elevado para su sustanciación ante la Corte IDH (Art.45 y 46) pues como señaló la Corte IDH en el caso Bayarri c. Argentina (2008) “...los motivos para el envío de un caso ante la Corte no pueden ser objeto de una excepción preliminar”.

La CIDH está facultada para decidir si somete el caso a la jurisdicción de la Corte Interamericana, en atención a lo que dicho organismo considere sea la alternativa más favorable para la tutela de los derechos establecidos en la Convención"49. Es particularmente importante, la opinión consultiva (2005) que emitió la CorteIDH en relación a una petición efectuada por Venezuela sobre este particular:

Existe [...] un ejercicio concurrente de competencias por parte de la Corte, al cual los Estados pueden acudir en caso de disconformidad con los hallazgos de la Comisión”...“cuando un caso es llevado ante el Tribunal, tanto la Comisión como la Corte interpretan la Convención respecto de los mismos hechos...Si un Estado está en desacuerdo con los hallazgos de la Comisión y considere [...] que no es de justicia cumplir con sus recomendaciones, la Convención le ofrece la oportunidad [de] someter el asunto a la competencia de la Corte”...la Corte Interamericana de Derechos Humanos, en el ejercicio de sus funciones, efectúa el control de legalidad de las actuaciones de la Comisión Interamericana de

\footnotetext{
${ }^{49}$ CorteIDH. Caso Bayarri Vs. Argentina. Sentencia de (Excepción Preliminar, Fondo, Reparaciones y Costas), 30 de octubre de 2008. Serie C No. 187, párr. 20.
} 
Derechos Humanos en lo que se refiere al trámite de los asuntos que estén bajo el conocimiento de la propia Corte $^{50}$.

\section{RESPONSABILIDAD INTERNACIONAL DEL ESTADO Y SANCIONES DE LA COMUNIDAD INTERNACIONAL:}

Como defendimos anteriormente, las sentencias de la Corte IDH y las resoluciones administrativas de órganos de protección de derechos humanos, como la $\mathrm{CIDH}$, son jurídicamente vinculantes pero no son ejecutables por medios forzosos pues la resistencia a la ejecución es el último bastión de la soberanía estatal. Sobre esta cuestión podríamos invocar argumentos como el respeto a los principios de no intervención en asuntos internos y el de no agresión interestatal, recogidos en la Carta de las Naciones Unidas y la Carta de la OEA, que en su artículo 19 dispone "ningún Estado o grupo de Estados tiene derecho de intervenir, directa o indirectamente, y sea cual fuere el motivo, en los asuntos internos o externos de cualquier otro. El principio anterior excluye no solamente la fuerza armada, sino también cualquier otra forma de injerencia...”.

Sin embargo, toda regla tiene una excepción que confirma su generalidad. Así, la Carta Democrática Interamericana señala que cuando en un "Estado Miembro se produzca una alteración del orden constitucional que afecte gravemente su orden democrático" (Art.20) la Asamblea General de la OEA podrá, tras agotar un procedimiento y siempre que este sea infructuoso, "suspender a dicho Estado Miembro del ejercicio de su derecho de participación en la OEA con el voto afirmativo de los dos tercios de los Estados Miembros. La suspensión entrará en vigor de inmediato” (Art.21). Este mecanismo no exime al Estado suspendido de cumplir las obligaciones que derivan de la pertenencia a la Organización, especialmente, en derechos humanos.

Además de la suspensión de la OEA, el hecho que de que el orden constitucional de un Estado miembro haya sido quebrantado de mutuo propio por su gobierno puede subsumirse en el presupuesto de violación a la "independencia política" de un Estado Americano sin "agresión armada”, y por ende, puede implicar que por medidas de "seguridad colectiva" como expresamente reza la Carta de la OEA se adopten medidas coercitivas de excepción (Art.29). De tal manera, el Tratado Interamericano de Asistencia Recíproca de 1947 establece como medios de presión para la restitución del orden democrático “...la ruptura de las relaciones diplomáticas; la ruptura de las relaciones consulares; la interrupción parcial o total de las relaciones económicas, o de las comunicaciones ferroviarias, marítimas, aéreas, postales, telegráficas, telefónicas, radiotelefónicas o radiotelegráficas, y el empleo de la fuerza armada” (Art.8).

Una organización regional como la OEA puede tomar medidas coercitivas no violentas contra un Estado Miembro de la OEA, con la simple notificación para fines informativos, al Consejo de Seguridad de la ONU. Entre estas medidas no violentas se encuentran el bloqueo comercial o sanciones de carácter político, como la ruptura de

\footnotetext{
${ }^{50}$ Corte IDH, “Opinión consultiva OC-19/05 de 28 de noviembre de 2005” solicitada por la República Bolivariana de Venezuela sobre el control de legalidad en el ejercicio de las atribuciones de la CIDH, recuperada el 6 de abril de 2017, en: http://www.corteidh.or.cr/docs/opiniones/seriea_19_esp1.pdf
} 
relaciones diplomáticas. Sin embargo, cuando una medida implique el uso de fuerza armada requiere la aprobación del Consejo de Seguridad, de acuerdo a la interpretación dada al artículo 53 de la Carta de la ONU. Finalmente, para que las medidas coercitivas de carácter económico, político y militar tengan validez y obligatoriedad universal, es decir, que se apliquen a Estados que no son miembros de la OEA, deben ser adoptadas necesariamente por el Consejo de Seguridad de la Organización de las Naciones Unidas $^{51}$.

Y he aquí la situación en torno a Venezuela, luego de que el estado denunciará la CADH, procedió también a denunciar el Tratado Interamericano de Asistencia Recíproca de 1948 (en adelante TIAR) el 14 de mayo de 2013, a través de la nota II.2E8.D-OEA.10-2605, ante la Secretaría General de la OEA. De acuerdo al artículo 25 del TIAR la denuncia de Venezuela surtió efectos definitivos en mayo del 2015 y por tanto todas las disposiciones del tratado le son inaplicables. Ello nos conduce a tres escenarios teóricamente posibles: que la OEA con fundamento en una relatoría especial sobre la situación de Venezuela, o apoyada en un conjunto de decisiones dictadas por la CIDH (control cuasi-jurisdiccional de convencionalidad) proceda a suspender al Estado Venezolano de la Organización de conformidad a la Carta Democrática sin poder adoptar medidas coercitivas y vinculantes para sus miembros bajo el TIAR. A nivel interamericano, la suspensión de la OEA y la aplicación medidas coercitivas (de ser aplicable el TIAR para Venezuela) sería factible dada la naturaleza y la escala del conflicto. De hecho, este régimen ha sido utilizado en contra de Republica Dominicana (1960), Cuba (1962), Haití (1991) y Honduras (2001). Esta opción ha sido bloqueada en el Seno de la OEA por una apretada votación.

Otra vía teóricamente posible es que la OEA, como órgano regional, inste al Consejo de Seguridad de la Organización de las Naciones Unidad (en adelante ONU) a adoptar las medidas de presión reconocidas por el derecho internacional en contra de Venezuela. Sin embargo, dada la naturaleza y alcance de los conflictos en los que interviene el Consejo de Seguridad consideramos que ello además de poco probable sería altamente cuestionable puesto que la misión primordial del Consejo de Seguridad de la ONU es preservar la paz y la seguridad mundial (Art.24) cuando existe un riesgo contra la Comunidad Internacional en su conjunto, cuestión que no concurre en el caso de Venezuela, donde el conflicto es de carácter político, económico y humanitario, y donde no existe capacidad militar ofensiva que ponga en riesgo la seguridad de ningún estado.

Finalmente, existe en nuestro criterio una tercera opción -en consideración a que la OEA decidió no suspender a Venezuela de la OEA- que los Estados miembros de la OEA de manera individual o de manera conjunta, aunque no bajo el auspicio de la Organización, en un ejercicio de discrecionalidad, adopten medidas de coerción económica y política permitidas bajo el derecho internacional a título propio, como por

\footnotetext{
${ }^{51}$ El artículo 53 de la Carta de las Naciones Unidas establece: "El Consejo de Seguridad utilizará dichos acuerdos u organismos regionales, si a ello hubiere lugar, para aplicar medidas coercitivas bajo su autoridad. Sin embargo, no se aplicarán medidas coercitivas en virtud de acuerdos regionales o por organismos regionales sin autorización del Consejo de Seguridad...”. véase al respecto, PEZZANO, L. "La adopción de medidas coercitivas por los organismos regionales: un análisis del artículo 53 de la Carta de las Naciones Unidas a la luz de la práctica de la OEA." Anuario mexicano de derecho internacional, Vol.12/2012, pp. 262 y ss.
} 
ejemplo, la ruptura de relaciones económicas y diplomáticas, económicas, de transporte y comunicación entre otras, siempre y cuando los medios no impliquen uso de la fuerza o intervención en asuntos internos. En este sentido, es preciso recordar que "los Estados individuales son siempre libres de terminar las relaciones económicas sería entonces extraño argumentar que cuando los Estados individuales se organizan en grupo, esta libertad deja de existir" 52 . A nuestro criterio, en Venezuela existe un quebrantamiento del orden constitucional a través de un auto-golpe de Estado, caracterizado por el abuso de la justicia constitucional, con el objeto de suprimir la función legislativa y la justicia ordinaria $^{53}$.

El mecanismo de sanciones económicas y políticas “coordinadas” ha sido aplicado con anterioridad en este tipo de conflictos, por ejemplo, la OEA recomendó en el caso de Haití (golpe de estado) “...una acción que procure el aislamiento diplomático de quienes detentan de hecho el poder en Haití...Recomendar a todos los Estados que suspendan sus vínculos económicos, financieros y comerciales con Haití, así como la ayuda y cooperación técnica que fuera del caso" ${ }^{54}$.

\section{CONCLUSIONES}

1. En relación a las medidas de gracia, como el indulto o la amnistía, la CorteIDH ha mantenido una jurisprudencia generalmente contraria al otorgamiento de medidas de gracia puesto que aquellas propician la impunidad de graves

\footnotetext{
52،[N]o se puede considerar que lo que está permitido a los Estados individualmente les está prohibido a los Estados colectivamente. Así pues, los acuerdos regionales pueden adoptar medidas de presión con los mismos requisitos y los mismos límites que los Estados en su actuación individual: a) cumplir los requisitos de legitimación activa, ya sea porque están legitimados para adoptar medidas en el marco de las relaciones de responsabilidad internacional, ya sea porque los mismos Estados destinatarios de las mismas le han atribuido previamente la competencia para adoptar ese tipo de medidas para el caso de que se diera ese supuesto concreto; y b) no violar, en ningún caso, los principios de no intervención en los asuntos internos y de prohibición del uso de la fuerza armada...”. véase al respecto, PEZZANO, L. "La adopción de medidas coercitivas por los organismos regionales: un análisis del artículo 53 de la Carta de las Naciones Unidas a la luz de la práctica de la OEA." Anuario mexicano de derecho internacional, Vol.12/2012, pp. 264 y ss.

${ }^{53}$ Como expresamente lo señaló la Asamblea Nacional de Venezuela a través del "Acuerdo exhortando al cumplimiento de la Constitución y sobre la responsabilidad del poder Ejecutivo nacional, del Tribunal Supremo de Justicia y del Consejo Nacional Electoral para la preservación de la paz y ante el cambio democrático en Venezuela”, del 10 de mayo de 2016, por la que solicita expresamente a la OEA la activación de la Carta Democrática Interamericana. Del aquel texto podemos resaltar lo siguiente: "Denunciar la ruptura del orden constitucional y democrático en Venezuela, materializado en la violación a las disposiciones constitucionales por parte del Poder Ejecutivo Nacional, del Tribunal Supremo de Justicia y del Consejo Nacional Electoral”... “Exigir a los magistrados de la Sala Constitucional del Tribunal Supremo de Justicia que sean intérpretes estrictos del texto constitucional; que no incurran en abusos en el ejercicio de la función jurisdiccional y a que hagan valer la independencia del Poder Judicial frente a los intereses de Nicolás Maduro Moros”. Recuperado el 6 de abril de 2017, en http://prensa.ula.ve/2016/05/12/acuerdo-de-la-asamblea-nacional-para-la-preservaci\%C3\%B3n-de-la-pazante-el-cambio-democr\%C3\%A1tico
}

${ }^{54}$ SELLA, O. E. “La caída de Aristide: crónica de una frustración popular”. Editorial Eduvim, Argentina, 2011, pp. 217.

Revista de Estudios Jurídicos nº 17/2017 (Segunda Época)

ISSN-e 2340-5066. Universidad de Jaén (España)

Versión electrónica: rej.ujaen.es 
violaciones a derechos humanos y conllevan el incumplimiento de obligaciones estatales relativas al acceso a la justicia, la verdad y la reparación de las víctimas del conflicto. En este sentido, la CorteIDH ha declarado la inconvencionalidad de varias leyes de amnistía en Latinoamérica. Sin embargo, si la norma de gracia cumple los estándares interamericanos aquella podría ser avalada por el Tribunal, esto en base a un argumento a fortiori: quien puede declarar inválida una norma en base al derecho internacional también podría reconocer su validez ante el mismo régimen.

2. Existen tres estándares en la jurisprudencia interamericana para determinar si una ley de amnistía es válida ante la jurisprudencia interamericana. En primer lugar, una medida de gracia no puede disminuir o eliminar la responsabilidad penal, civil y administrativa de los responsables de los crímenes tipificados en el Estatuto de Roma bajo ningún concepto. En segundo lugar, la amnistía debe garantizar por lo menos un procedimiento cuasi-jurisdiccional (Comisiones de la Verdad) que permitan a las víctimas y sus familiares conocer la realidad de los hechos y permitirles el acceso a la justicia civil y administrativa. Además, debe proporcionarse por parte del Estado reparaciones que pueden ser simbólicas, económicas y garantías de no repetición. Finalmente, la medida de gracia debe ser adoptada en un régimen de democracia deliberativa, siendo fruto de un verdadero ánimo de reconciliación social y no una norma de auto amnistía que resulta nula desde su expedición.

3. Es posible que un Estado ejerza una especie constitucionalismo abusivo utilizando el poder de control de constitucionalidad de las leyes de manera manifiestamente contraria al derecho internacional con el objeto de erosionar el orden democrático. Todos los jueces, como agentes estatales, están llamados a ejercer un control de convencionalidad de oficio y por tanto una desviación manifiesta constituye una infracción que genera responsabilidad estatal.

4. Sin embargo, el hecho de que un Tribunal Constitucional no reconozca una sentencia en particular de la Corte IDH no conlleva automáticamente al quebrantamiento del orden democrático. Una afirmación en este sentido implicaría desconocer el pluralismo constitucional de los Estados miembros del sistema interamericano de derechos humanos y dificultar el diálogo entre los tribunales nacionales y los internacionales.

5. En nuestro criterio, para que exista un constitucionalismo abusivo del esbozado en este trabajo, tiene que existir un sistema ilegítimo que impida que las minorías se conviertan en mayorías o que las mayorías puedan adoptar decisiones legítimas. Sostenemos que esto es lo que sucedió en Venezuela debido a acciones sistemáticas del Estado: la declaratoria judicial de que las sentencias de la Corte IDH son inejecutables en Venezuela, la denuncia de la CADH, la denuncia del TIAR y la violación concurrente de derechos humanos en el país. Este conjunto de actuaciones impedirían que la Corte IDH pueda juzgar al Estado y al mismo tiempo 
impedir que se tomen medidas económicas, políticas y militares en su contra. De igual manera, este tipo de régimen se caracteriza por una apariencia de legalidad y por mantener el conflicto dentro de ciertos límites (fuero interno) que no permitirían a la ONU emprender acciones legítimamente.

6. La ley de amnistía y reconciliación sancionada por el legislativo venezolano fue declarada inconstitucional por el fondo y en la totalidad de sus artículos en contravención manifiesta a los criterios de validez y nulidad establecidos por el derecho internacional. Existen serios indicios de la falta de imparcialidad e independencia del TSJ debido a su renovación irregular de magistrados. De igual manera, pese a que no existe una regulación legal expresa sobre medidas de gracia en Venezuela el Tribunal no respetó el principio pro legislatore. Finalmente, previo a la expedición de esta sentencia del TSJ, el ejecutivo venezolano aseguró que la ley no entraría en vigencia por inconstitucional (como de hecho sucedió) y solicitó al Alto Comisionado de las Naciones Unidas para los Derechos Humanos un informe legal sobre la norma cuestión. El Alto Comisionado concluyó que la norma era conforme al derecho internacional, es decir, que era válida.

\section{BIBLIOGRAFÍA CITADA:}

\section{LIBROS Y ARTÍCULOS:}

AYALA CORAO, C. "Comentarios sobre la sentencia de la Sala Constitucional del Tribunal Supremo de Justicia de Venezuela (No. 1939) de fecha 18-12-08”, Revista de Estudios Constitucionales, Vol.7 (1)/2009, pp. 391-395.

AYALA CORAO, C. "La criminalización de la protesta en Venezuela”, ¿Es legítima la criminalización de la protesta social?, Centro de estudios en libertad de expresión y acceso a la información, Universidad de Palermo, Argentina, 2010, pp. 209234.

DE LORA, P. "La Presunción de Constitucionalidad de las Leyes: Una Visita a la Regla Thayer”. Teoría Constitucional y Derechos Fundamentales. Comisión Nacional de Derechos Humanos, México, 2002, pp. 409 y ss.

DEL TORO HUERTA. M. I. "La responsabilidad del Estado en el marco del derecho internacional de los derechos humanos". In Memoria del VII Congreso Iberoamericano de Derecho Constitucional, 2002, pp. 663-688.

GARGARELLA, R. "La democracia frente a los crímenes masivos: una reflexión a la luz del caso Gelman”, recuperado el 6 de abril de 2017, en:

https://law.yale.edu/sites/default/files/documents/pdf/sela/SELA13_Gargarella CV_Sp_20120924.pdf

HUMAN RIGTHS WATCH. "Manipulando el Estado de Derecho: Independencia del Poder Judicial amenazada en Venezuela”, Vol. 16, No. 3 (B)/2004. 
HITTERS, J. C. "Control de constitucionalidad y control de convencionalidad. Comparación (Criterios fijados por la Corte Interamericana de Derechos Humanos)”. Estudios constitucionales, 7(2)/2009, pp. 109-128.

FERRER M.G, E. "Las siete principales líneas jurisprudenciales de la Corte Interamericana de Derechos Humanos aplicable a la justicia penal” Revista IIDH, Vol.59/2014, pp. 30 y ss.

LANDAU, D. “Abusive Constitutionalism”, University of California, Davis Law Review, Vol.47/2013, pp. 195 y ss.

MALARINO, E. "Breves reflexiones sobre la justicia de transición a partir de las experiencias latinoamericanas". Justicia de Transición: con informes de América Latina, Alemania, Italia y España. Montevideo: Fundación Konrad-Adenauer-Stiftung, Alemania, 2009, pp. 415-431.

MEDELLÍN, C. “Amnistía, Institución Iuspolítica”, Derecho Penal y Criminología, 11, Vol.259/1989.

MEZA, M. A. "La contribución de la jurisprudencia de la corte interamericana de derechos humanos a la eliminación de las «leyes de amnistía» en América Latina: un paso decisivo en la lucha contra la impunidad”. Recuperado el 6 de abril de 2017, en:

https://hal.archivesouvertes.fr/file/index/docid/531553/filename/AT16_Arenas.pdf

OCHOA, M. J. "La protección de los derechos humanos en Venezuela frente a la denuncia de la CADH". Revista Latinoamericana de Derechos Humanos, Vol.25/2015, pp. 196 y ss.

OVALLE, J. "La influencia de la jurisprudencia de la Corte Interamericana de Derechos Humanos en el derecho interno de los Estados latinoamericanos”. Boletín mexicano de derecho comparado, 45(134)/2012, pp. 595-623.

PEZZANO, L. "La adopción de medidas coercitivas por los organismos regionales: un análisis del artículo 53 de la Carta de las Naciones Unidas a la luz de la práctica de la OEA." Anuario mexicano de derecho internacional, Vol.12/2012, pp. 262 y ss.

SÁNCHEZ, J. M. S. “Nullum Crimen Sine Poena-Sobre las Doctrinas Penales de la Lucha Contra la Impunidad y del Derecho de la Victima al Castigo del Autor". Revista de Estudios de la Justicia, Vol.11/2009, pp. 38.

SELLA, O. E. "La caída de Aristide: crónica de una frustración popular”. Editorial Eduvim, Argentina, 2011, pp. 217.

SLYE, R. "Legitimacy of Amnesties under International Law and General Principles of Anglo-American Law: Is a Legitimate Amnesty Possible", the Seattle University School of Law Digital Commons, Vol. 43, 173/2002, pp. 174-215.

SYAMPA, M., \& PANDOLFI, C. "Las vías de la criminalización de la protesta en Argentina”. Observatorio Social de América Latina, Vol. 5(14)/2004, pp.285-296. 
TUSHNET, M. “Authoritarian Constitutionalism” Cornell Law Review, Vol.100/2015, pp. 391.

\section{SENTENCIAS Y OPINIONES CONSULTIVAS DE LA CORTE IDH:}

CorteIDH, caso Almonacid Arellano y otros Vs. Chile. Excepciones Preliminares, Fondo, Reparaciones y Costas, 26 de septiembre de 2006, Serie C No 154, párr. 105-129.

CorteIDH. Caso Bayarri Vs. Argentina. Sentencia de (Excepción Preliminar, Fondo, Reparaciones y Costas), 30 de octubre de 2008. Serie C No. 187, párr. 20.

CorteIDH. Caso Boyce y otros Vs. Barbados. Supervisión Cumplimiento Sentencia. Resolución de la Corte Interamericana de Derechos Humanos de 21 de noviembre de 2011.

CorteIDH. Caso La Cantuta Vs. Perú. Fondo, Reparaciones y Costas. Sentencia de 29 de noviembre de 2006. Serie C No. 162.

CorteIDH. Caso Goiburú y otros Vs. Paraguay. Fondo, Reparaciones y Costas. Sentencia de 22 de septiembre de 2006. Serie C No. 153.

CorteIDH. Caso de los “Niños de la Calle” (Villagrán Morales y otros) Vs. Guatemala. Reparaciones y Costas. Sentencia de 26 de mayo de 2001. Serie C No. 77, párr. 100.

CorteIDH, caso de las Masacres de Ituango Vs. Colombia, excepción preliminar, fondo, reparaciones y costas, sentencia de 1 de julio de 2006, Serie C No. 148, párr. 299 y 402.

CorteIDH. Caso Trabajadores Cesados del Congreso (Aguado Alfaro y otros) Vs. Perú. Excepciones Preliminares, Fondo, Reparaciones y Costas. Sentencia de 24 de noviembre de 2006. Serie C No. 158, párr. 128.

CorteIDH. Caso Las Palmeras Vs. Colombia. Fondo. Sentencia de 6 de diciembre de 2001. Serie C No. 90.

CorteIDH, Caso "Panel Blanca” (Paniagua Morales y otros) Vs. Guatemala. Sentencia de 8 de marzo de 1998. Serie C No. 37, párr. 173.

CorteIDH. Caso "La Última Tentación de Cristo" (Olmedo Bustos y otros) Vs. Chile. Fondo, Reparaciones y Costas. Sentencia de 5 de febrero de 2001. Serie C No. 73.

CorteIDH, caso Velásquez Rodríguez Vs. Honduras, Sentencia de 29 de julio de 1988 (Fondo), pág. 36. 
Corte IDH, “Opinión consultiva OC-19/05 de 28 de noviembre de 2005” solicitada por la República Bolivariana de Venezuela sobre el control de legalidad en el ejercicio de las atribuciones de la CIDH, recuperada el 6 de abril de 2017, en: http://www.corteidh.or.cr/docs/opiniones/seriea_19_esp1.pdf 